\title{
Recognition Properties of an Acyclic Biphenyl-Based Receptor toward Carbohydrates
}

\author{
Monika Mazik and Alexander König
}

Page

1. ${ }^{1} \mathrm{H}$ NMR titration of receptor $\mathbf{1}$ with $\beta$-maltoside $\mathbf{2}$ (chemical shifts of the S2 $\mathrm{NH}, \mathrm{CH}_{3}$ and the pyridine/biphenyl $\mathrm{CH}$ resonances).

2. ${ }^{1} \mathrm{H}$ NMR titration of receptor $\mathbf{1}$ with $\beta$-glucopyranoside $\mathbf{3}$ (chemical shifts of the $\mathrm{NH}, \mathrm{CH}_{3}$ and the pyridine/biphenyl $\mathrm{CH}$ resonances)

3. ${ }^{1} \mathrm{H}$ NMR titration of receptor $\mathbf{1}$ with $\beta$-glucopyranoside 3 : Plots of the chemical shifts of the $\mathrm{NH}$ and $\mathrm{CH}_{3}$ resonances as a function of added $\beta$-glucopyranoside

4. $\quad{ }^{1} \mathrm{H}$ and ${ }^{13} \mathrm{C}$ NMR spectra of compounds $\mathbf{1}, \mathbf{5}, \mathbf{8}$ and 9 .

5. Representative mole ratio plots.

6. Description of a titration experiment with dodecyl $\beta$-D-maltoside (2 $\beta$ ). 
1. ${ }^{1} \mathrm{H}$ NMR titration of $\mathbf{1}$ with $\beta$-maltoside $\mathbf{2} \beta$.

a)

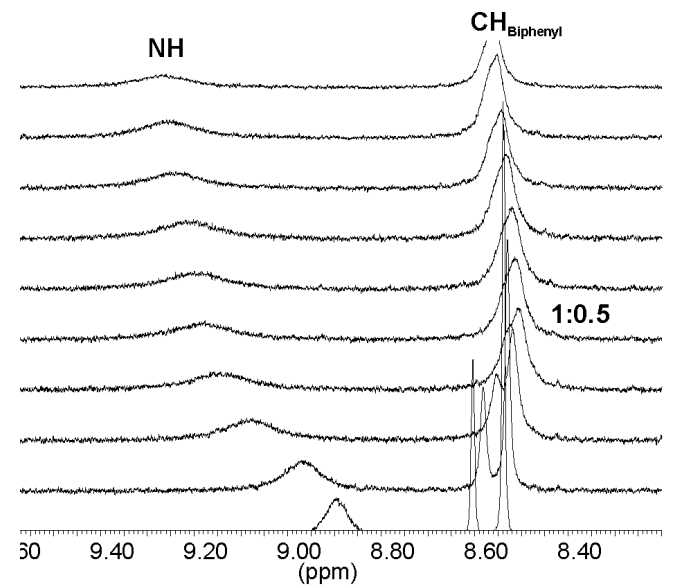

c)

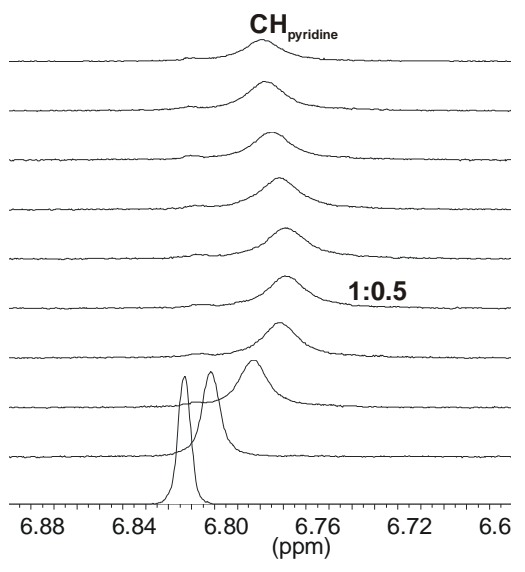

b)

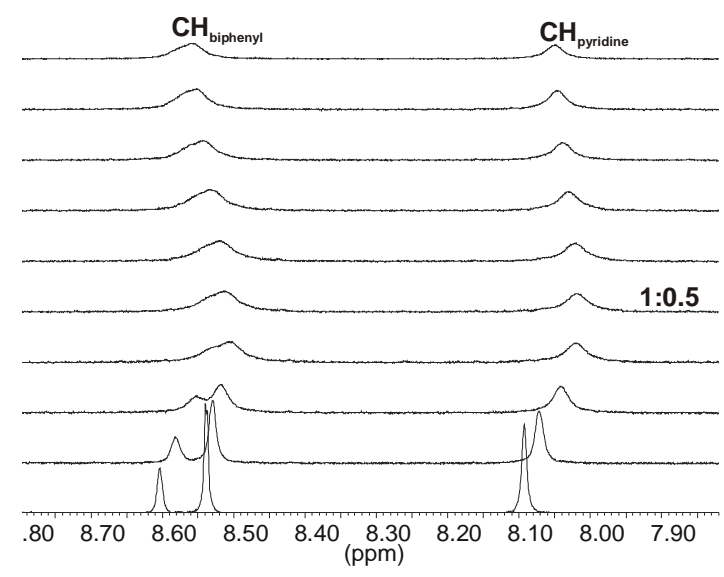

d)

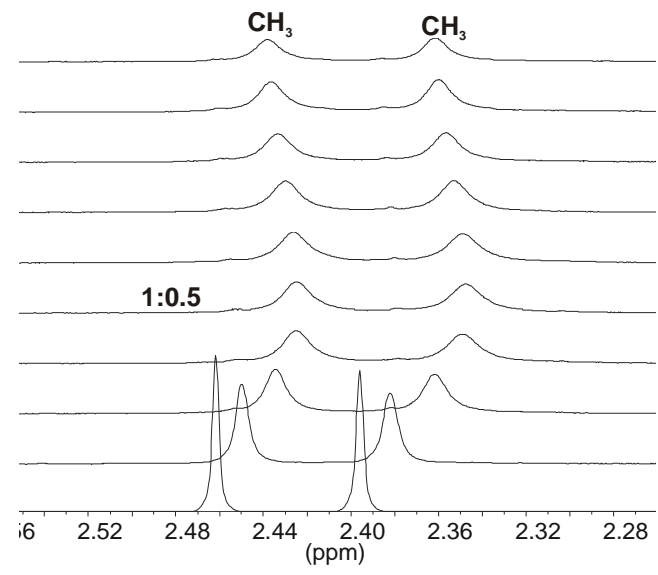

FIGURE S1. Partial ${ }^{1} \mathrm{H}$ NMR spectra $\left(500 \mathrm{MHz}, \mathrm{CDCl}_{3}, 25^{\circ} \mathrm{C}\right)$ of 1 after addition of (from bottom to top) $0.00-3.40$ equiv of $\mathbf{2} \beta([\mathbf{1}]=1.01 \mathrm{mM})$. The [receptor]:[sugar] ratio is marked. 
2. $\quad{ }^{1}$ H NMR Titration of receptor $\mathbf{1}$ with $\beta$-glucopyranoside 3 .

a)

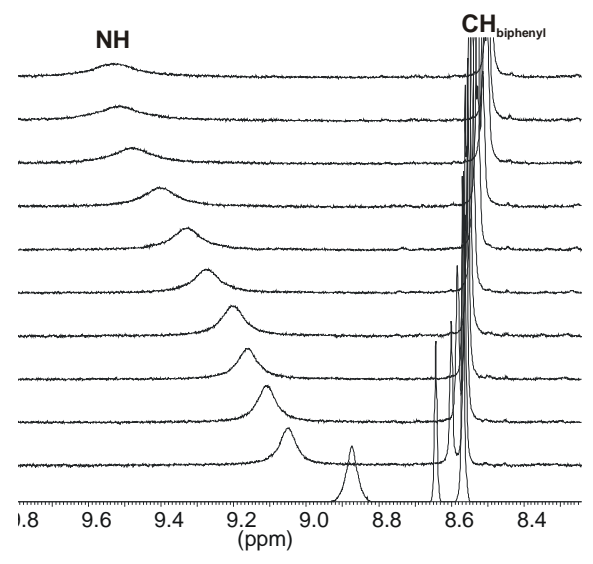

c)

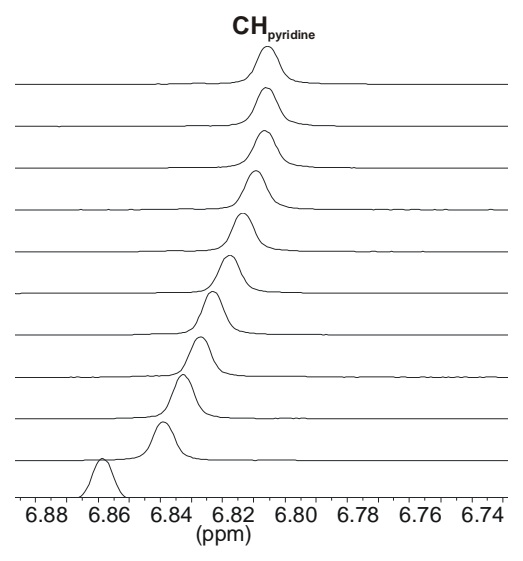

b)

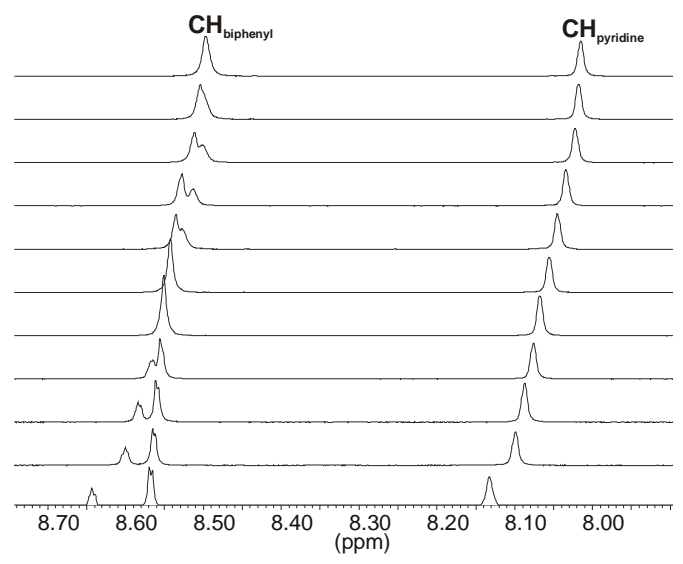

d)

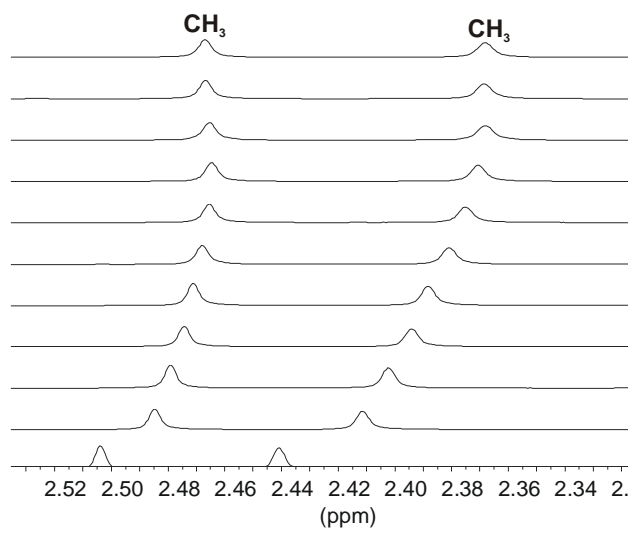

FIGURE S2. Partial ${ }^{1} \mathrm{H}$ NMR spectra $\left(500 \mathrm{MHz}, \mathrm{CDCl}_{3}, 25^{\circ} \mathrm{C}\right.$ ) of $\mathbf{1}$ after addition of (from bottom to top) 0.00-5.29 equiv of $\mathbf{3}([\mathbf{1}]=0.94 \mathrm{mM})$.

3. ${ }^{1} \mathrm{H}$ NMR Titration of $\mathbf{1}$ with $\beta$-glucopyranoside $\mathbf{3}$ in $\mathrm{CDCl}_{3}$ :Plots of the chemical shifts of the $\mathrm{NH}$ and $\mathrm{CH}_{3}$ resonances as a function of added $\beta$-glucopyranoside 3 .

a)

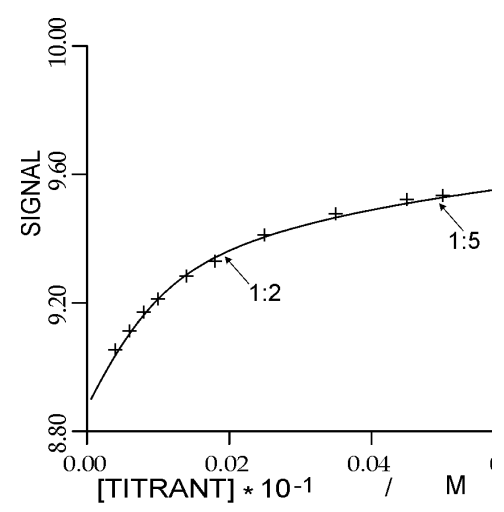

b)

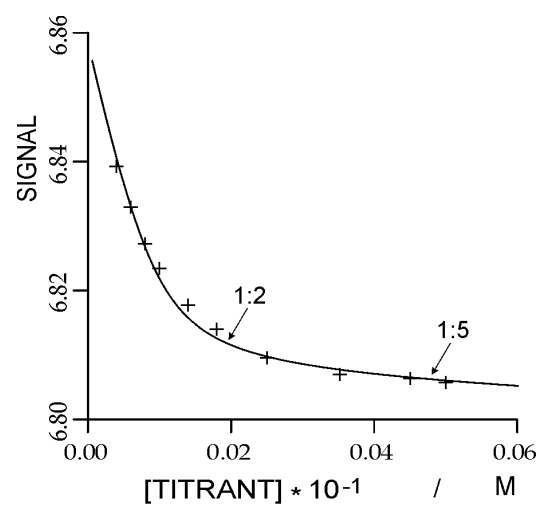


c)

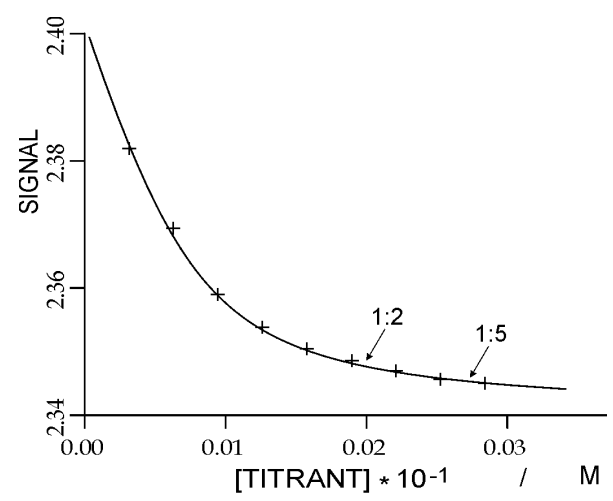

d)

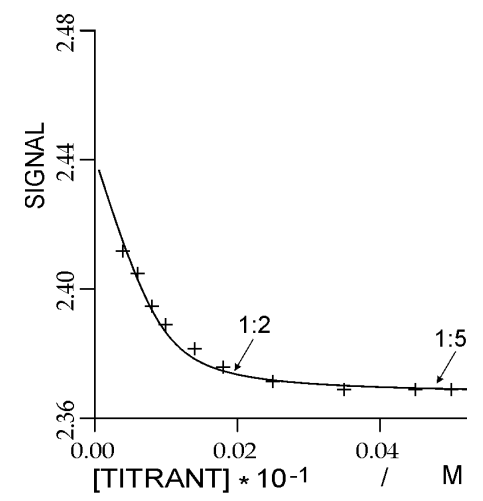

FIGURE S3. (a) Plot of the observed (x) and calculated (-) downfield chemical shifts of the the NH (a), pyridine $\mathrm{CH}(\mathrm{b})$, and $\mathrm{CH}_{3}(\mathrm{c}, \mathrm{d})$ resonances of $\mathbf{1}$ as a function of added $\beta$-glucopyranoside $\mathbf{3}$; [1] = $0.94 \mathrm{mM}$. The [receptor]:[sugar] ratio is marked.

4. ${ }^{1} \mathrm{H}$ and ${ }^{13} \mathrm{C}$ NMR Spectra of compounds 5, 8, 9 and $\mathbf{1}$.

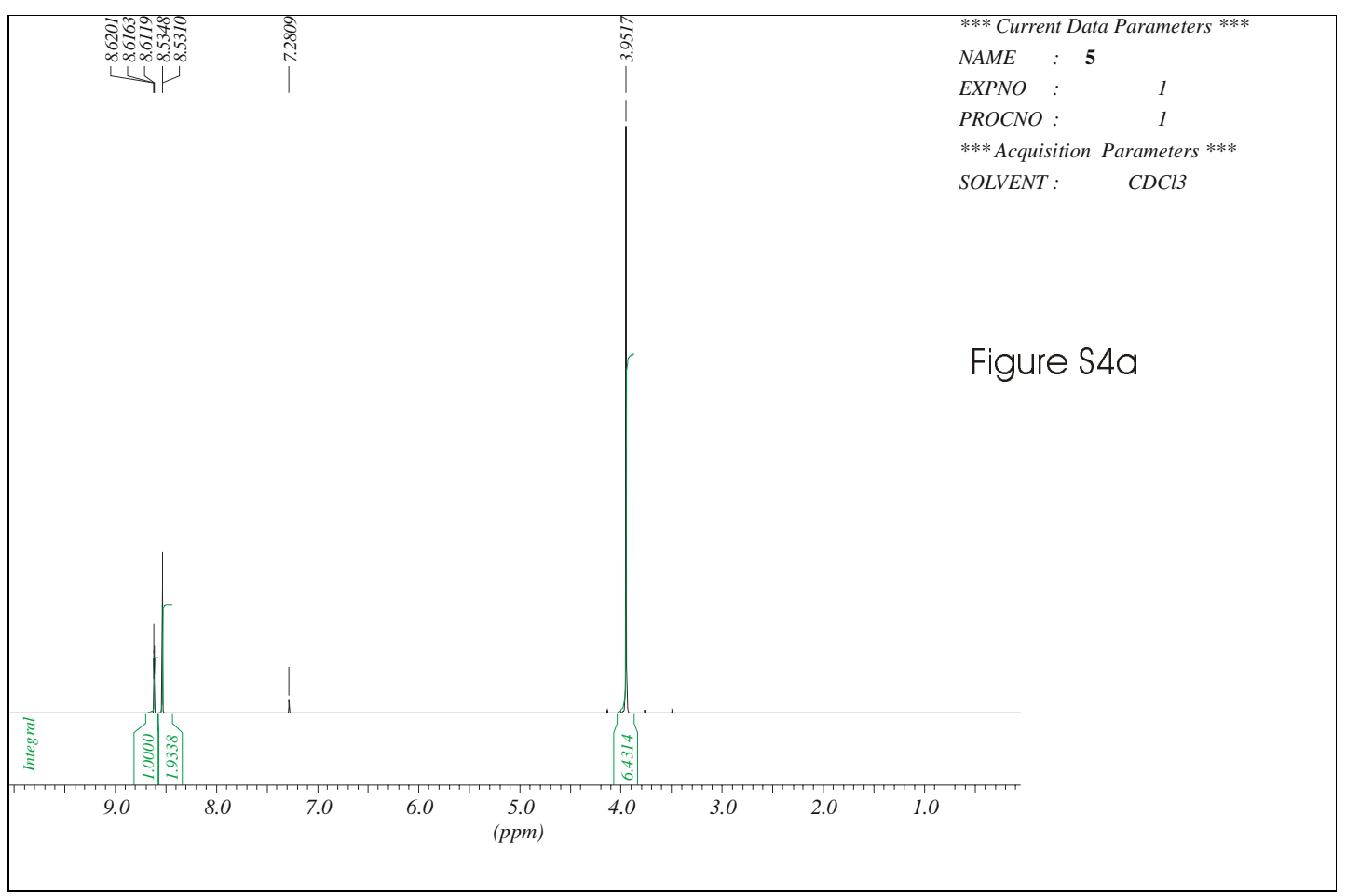




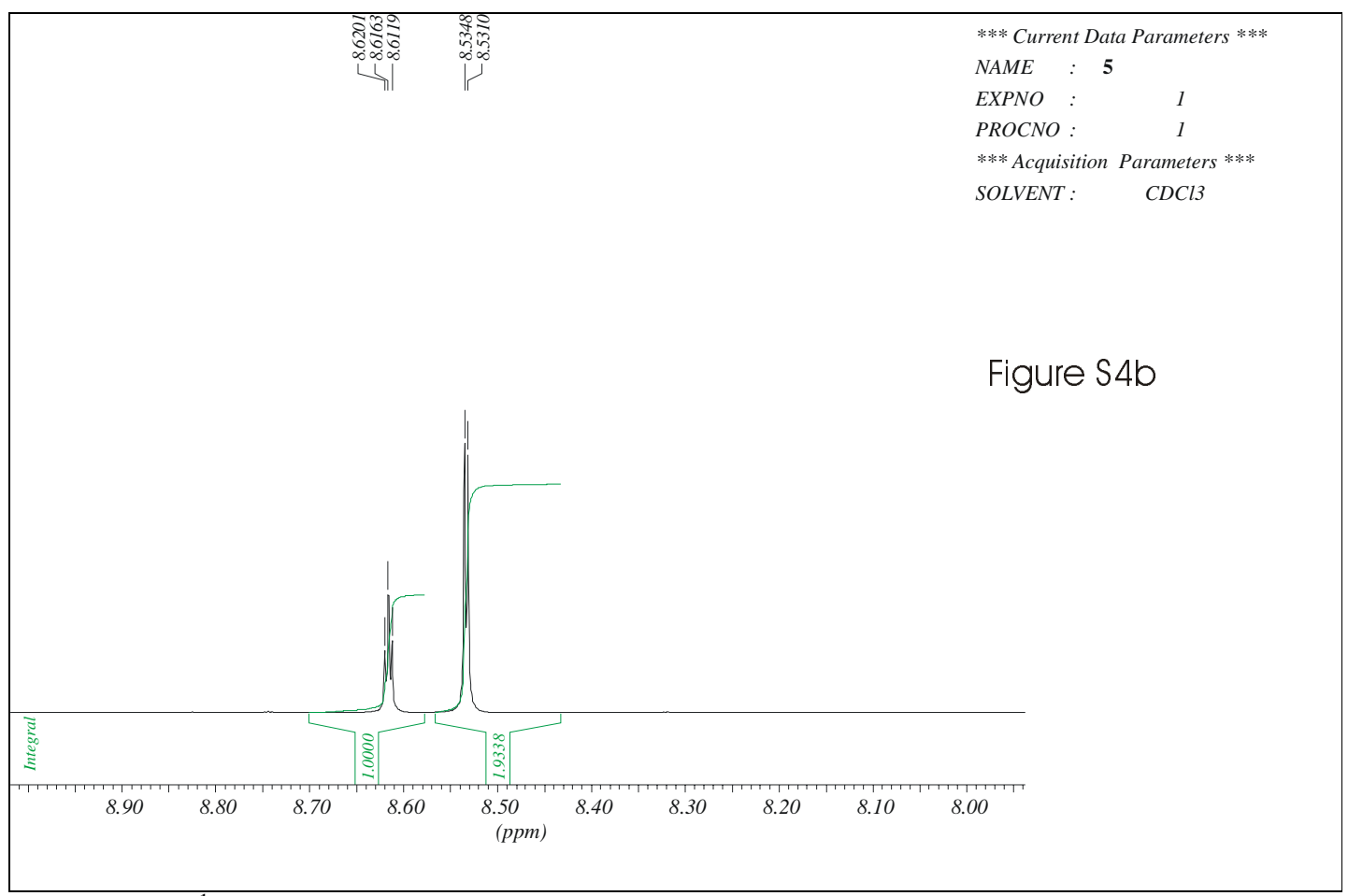

FIGURE S4. ${ }^{1} \mathrm{H}$ NMR Spectrum of $5\left(\mathrm{CDCl}_{3}, 400 \mathrm{MHz}\right)$.

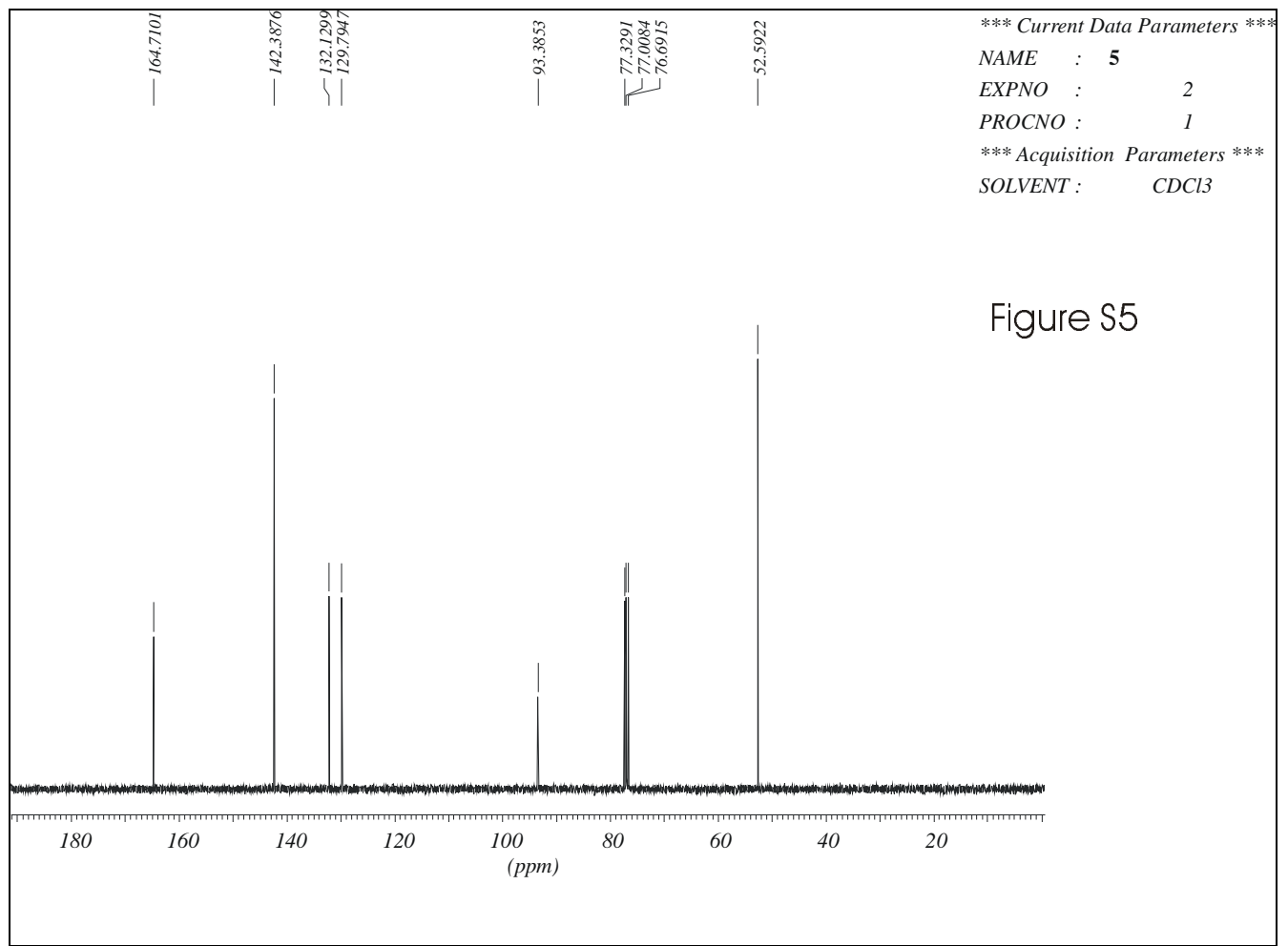

FIGURE S5. ${ }^{13} \mathrm{C}$ NMR Spectrum of $5\left(\mathrm{CDCl}_{3}\right)$. 


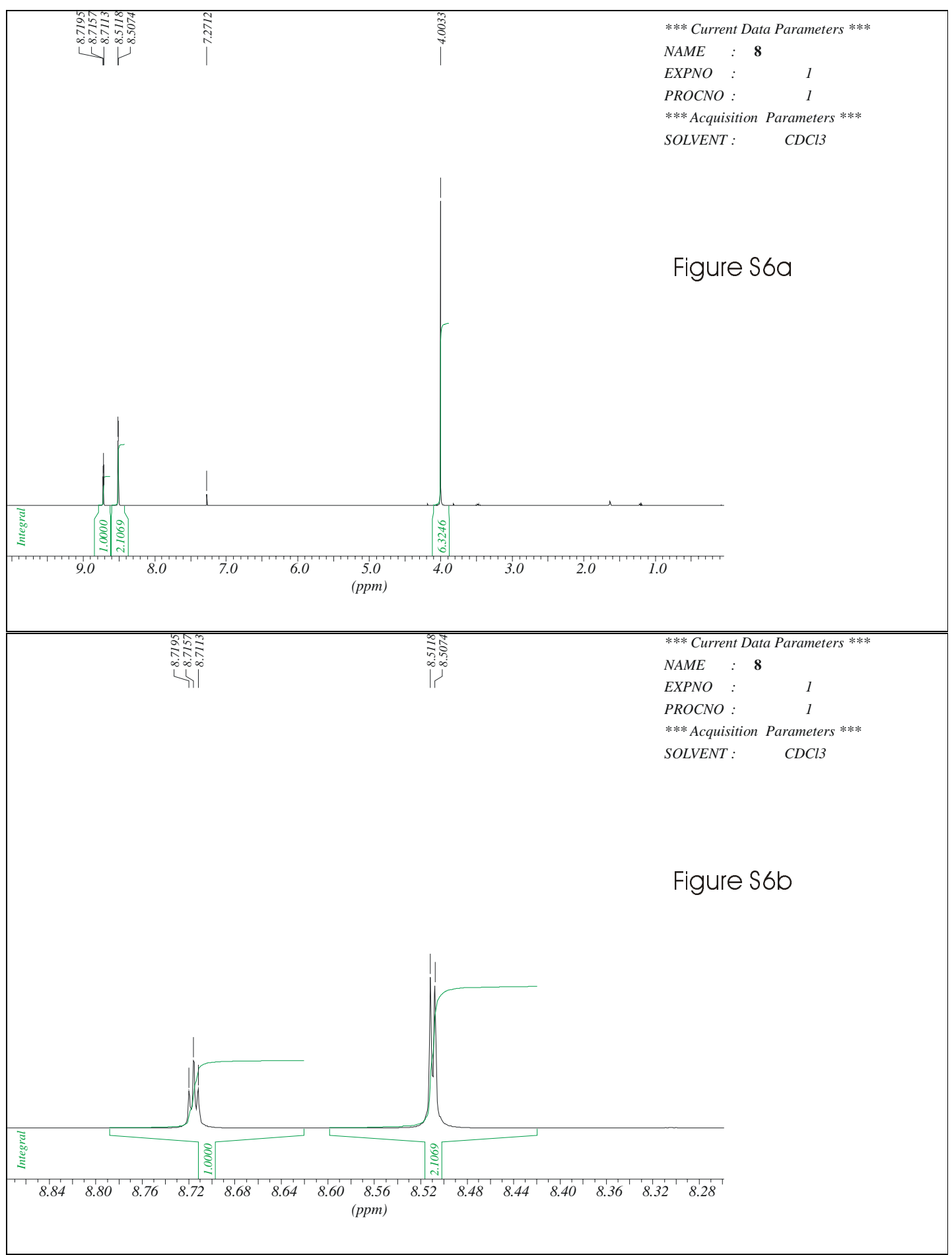

FIGURE S6. ${ }^{1} \mathrm{H}$ NMR Spectrum of $8\left(\mathrm{CDCl}_{3}, 400 \mathrm{MHz}\right)$. 

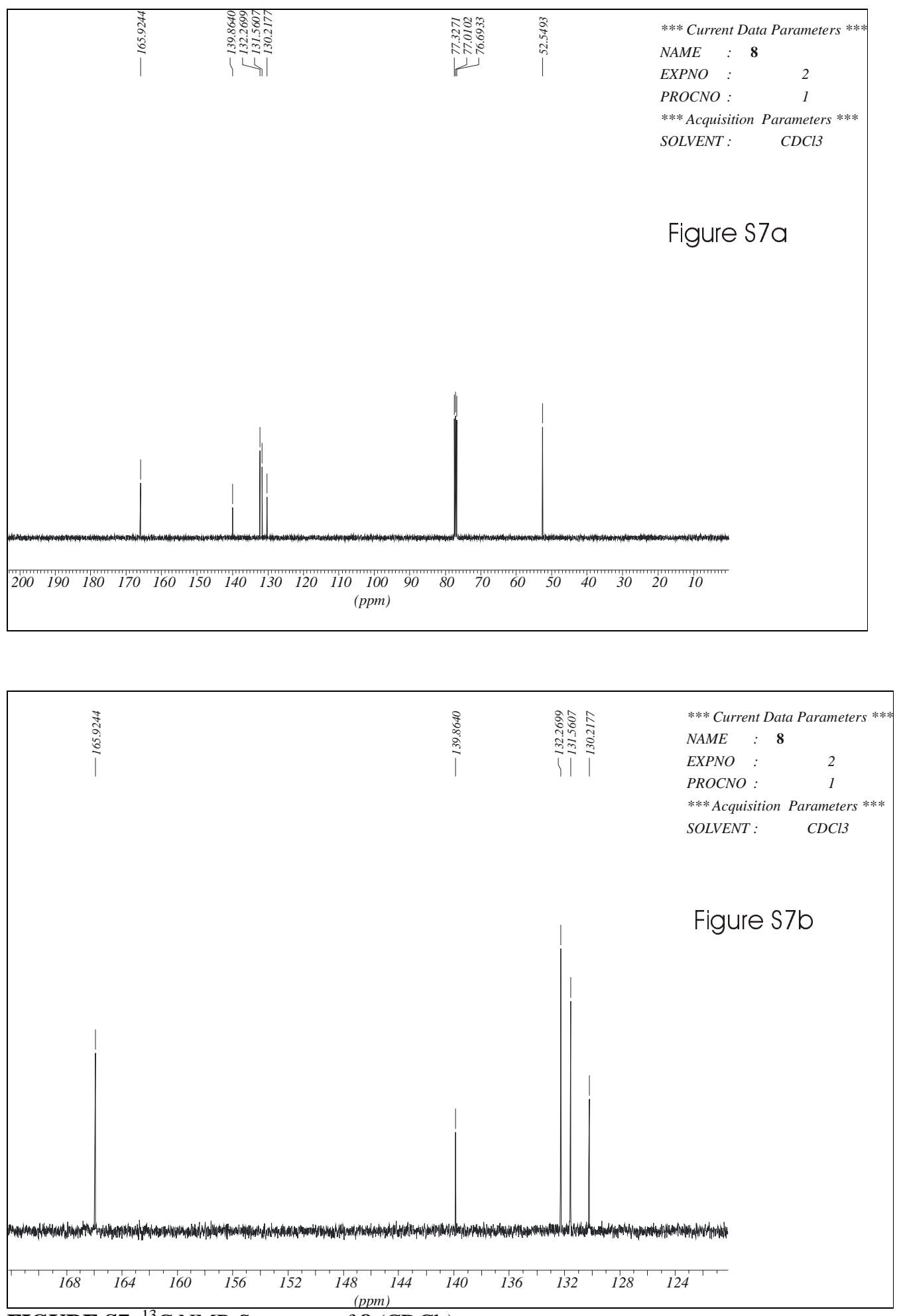

FIGURE S7. ${ }^{13} \mathrm{C}$ NMR Spectrum of $\mathbf{8}\left(\mathrm{CDCl}_{3}\right)$. 


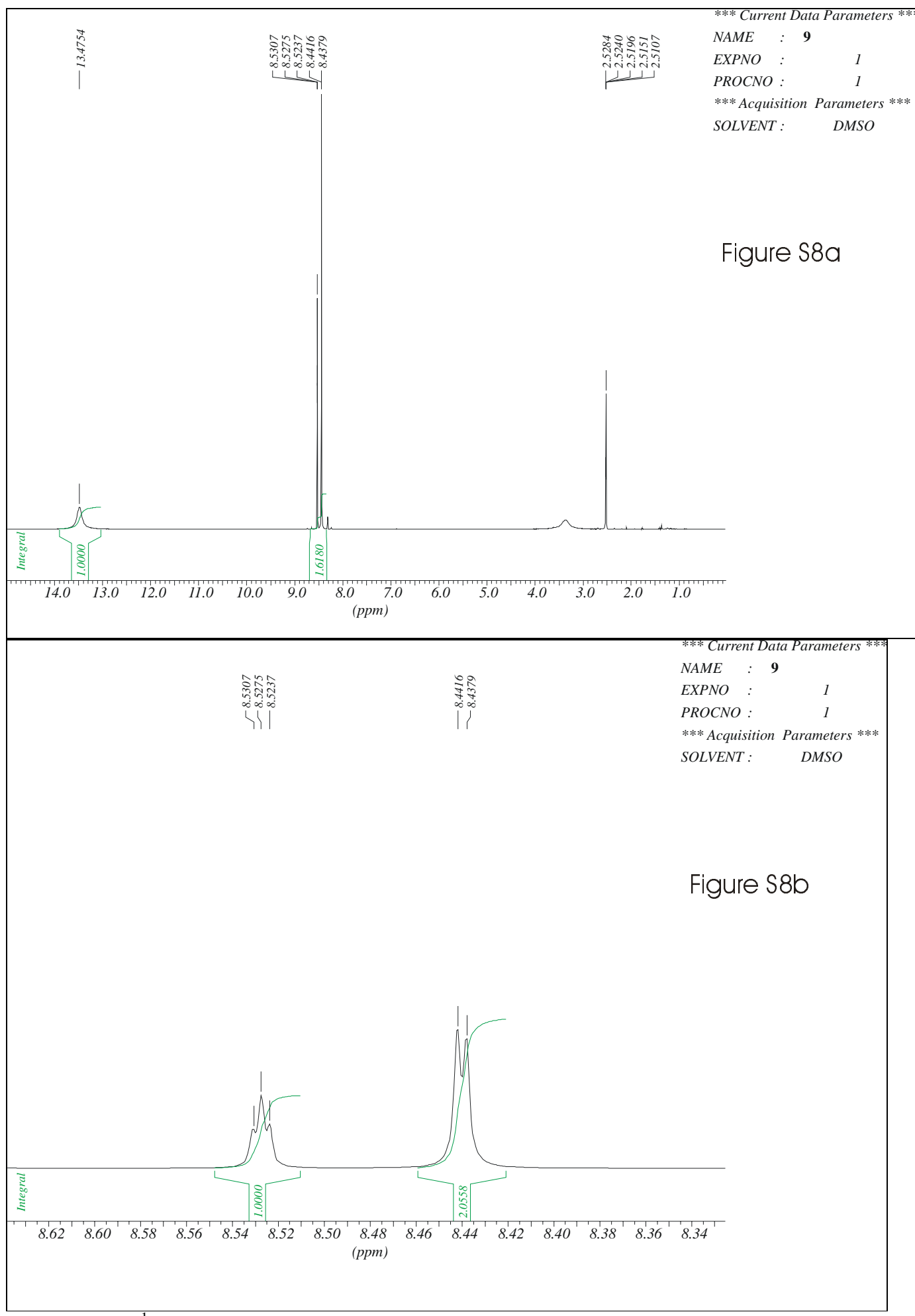

FIGURE S8. ${ }^{1} \mathrm{H}$ NMR Spectrum of 9 (DMSO-d 6 , $\left.400 \mathrm{MHz}\right)$. 


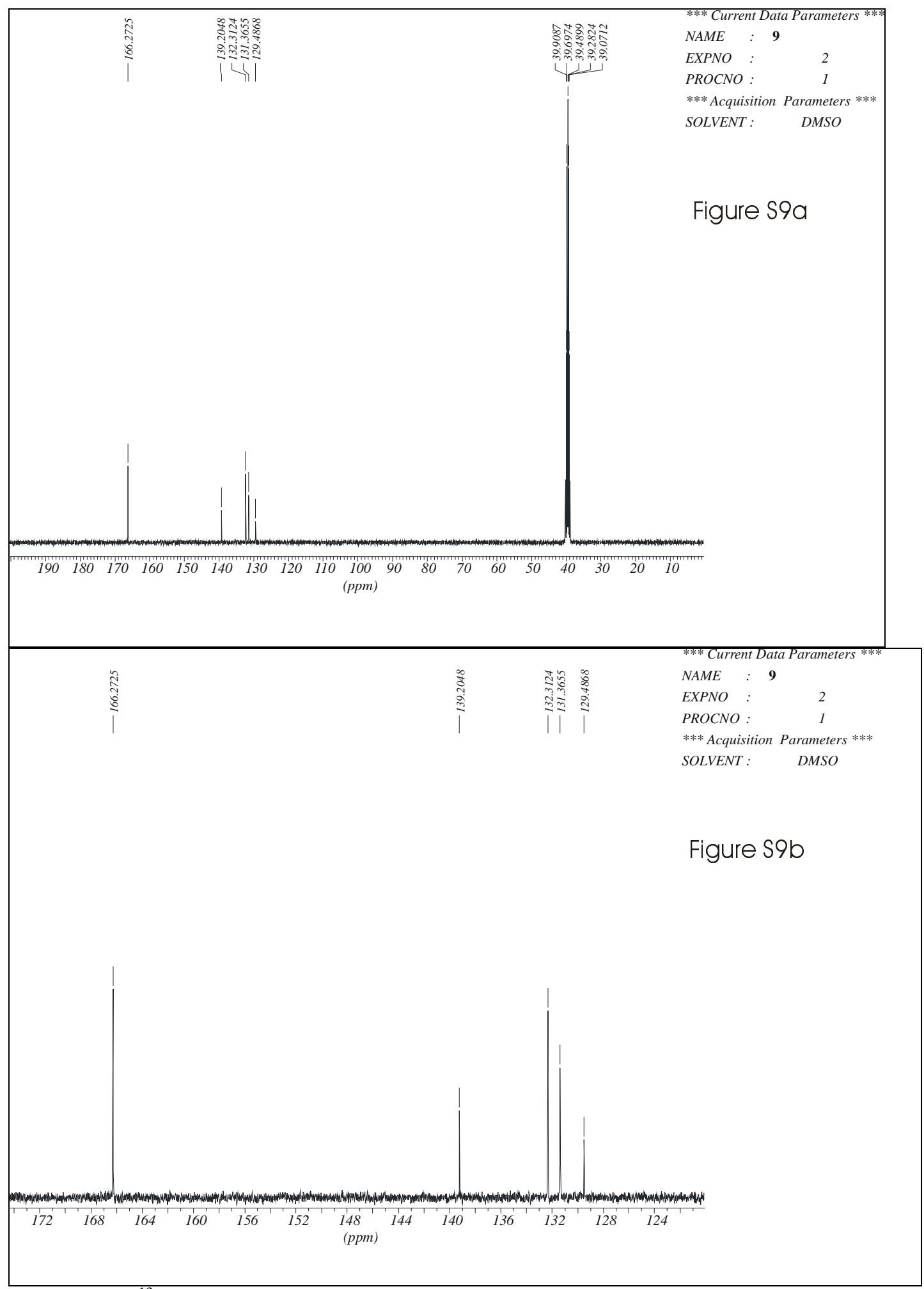

FIGURE S9. ${ }^{13} \mathrm{C}$ NMR Spectrum of $9\left(\right.$ DMSO-d $\left._{6}\right)$. 


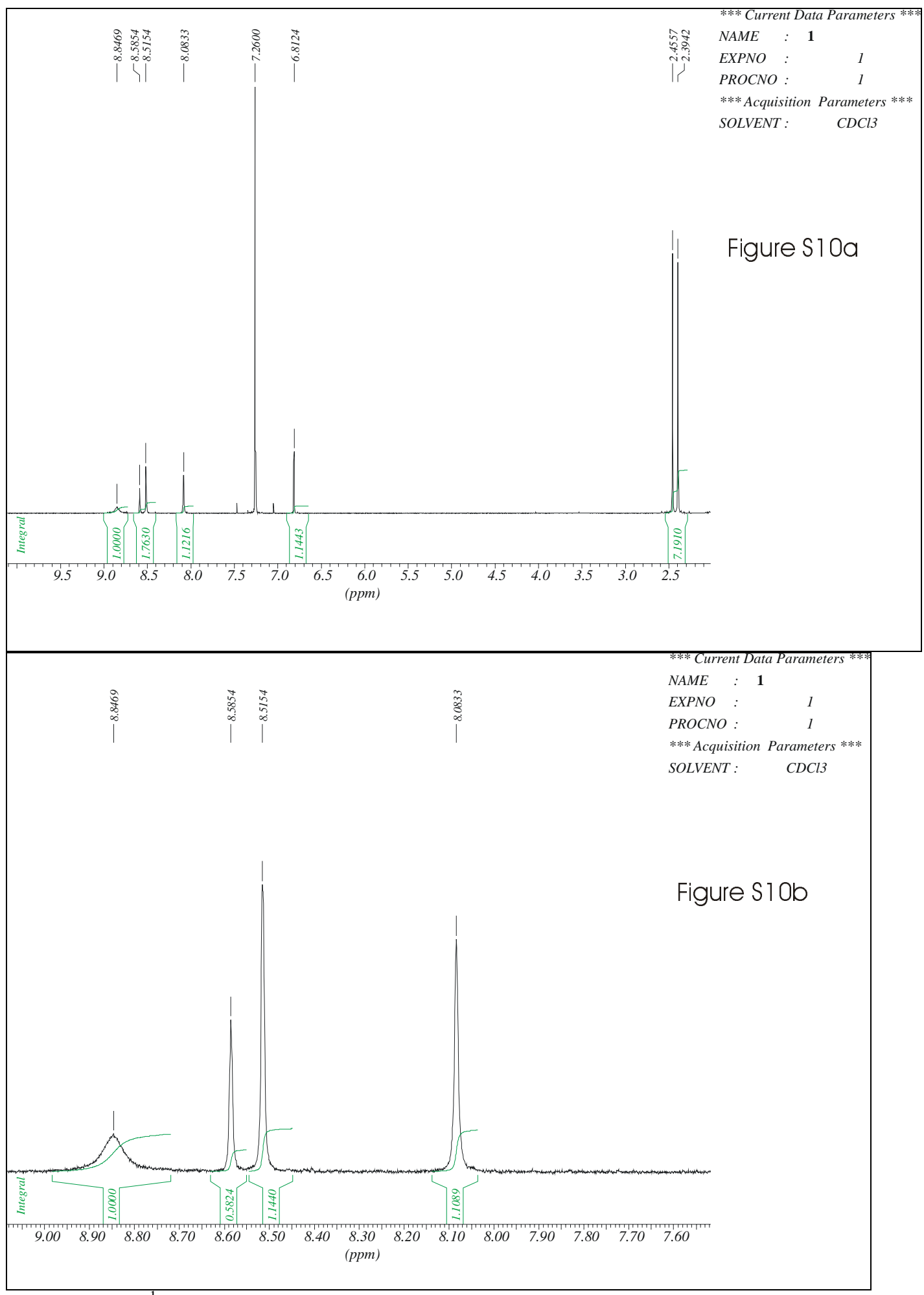

FIGURE S10. ${ }^{1} \mathrm{H}$ NMR Spectrum of $1\left(\mathrm{CDCl}_{3}, 500 \mathrm{MHz} ;[1]=0.9 \mathrm{mM}\right)$. 


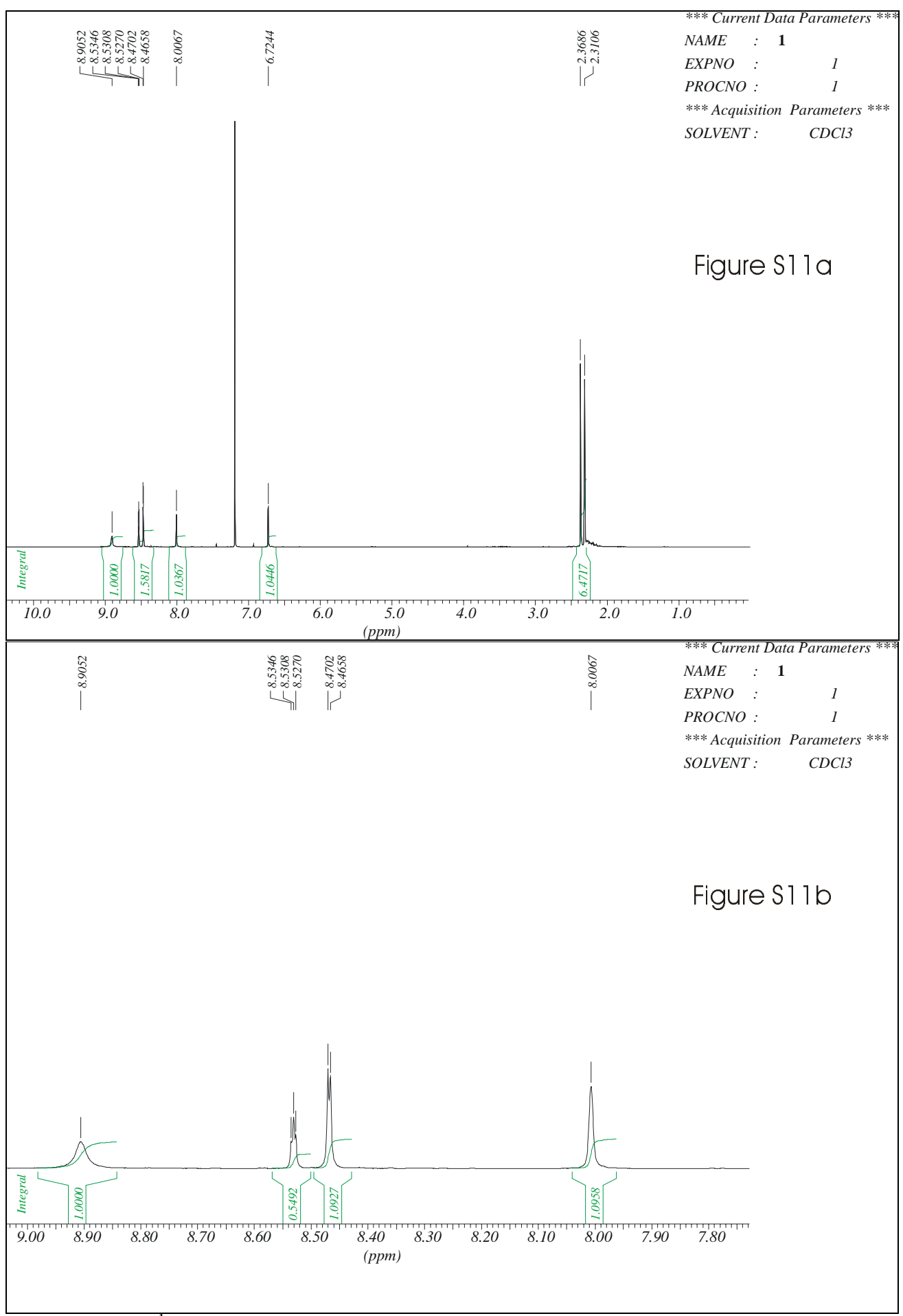

FIGURE S11. ${ }^{\mathrm{H}} \mathrm{H}$ NMR Spectrum of $\mathbf{1}\left(\mathrm{CDCl}_{3}, 400 \mathrm{MHz} ;[\mathbf{1}]=5.3 \mathrm{mM}\right)$. 


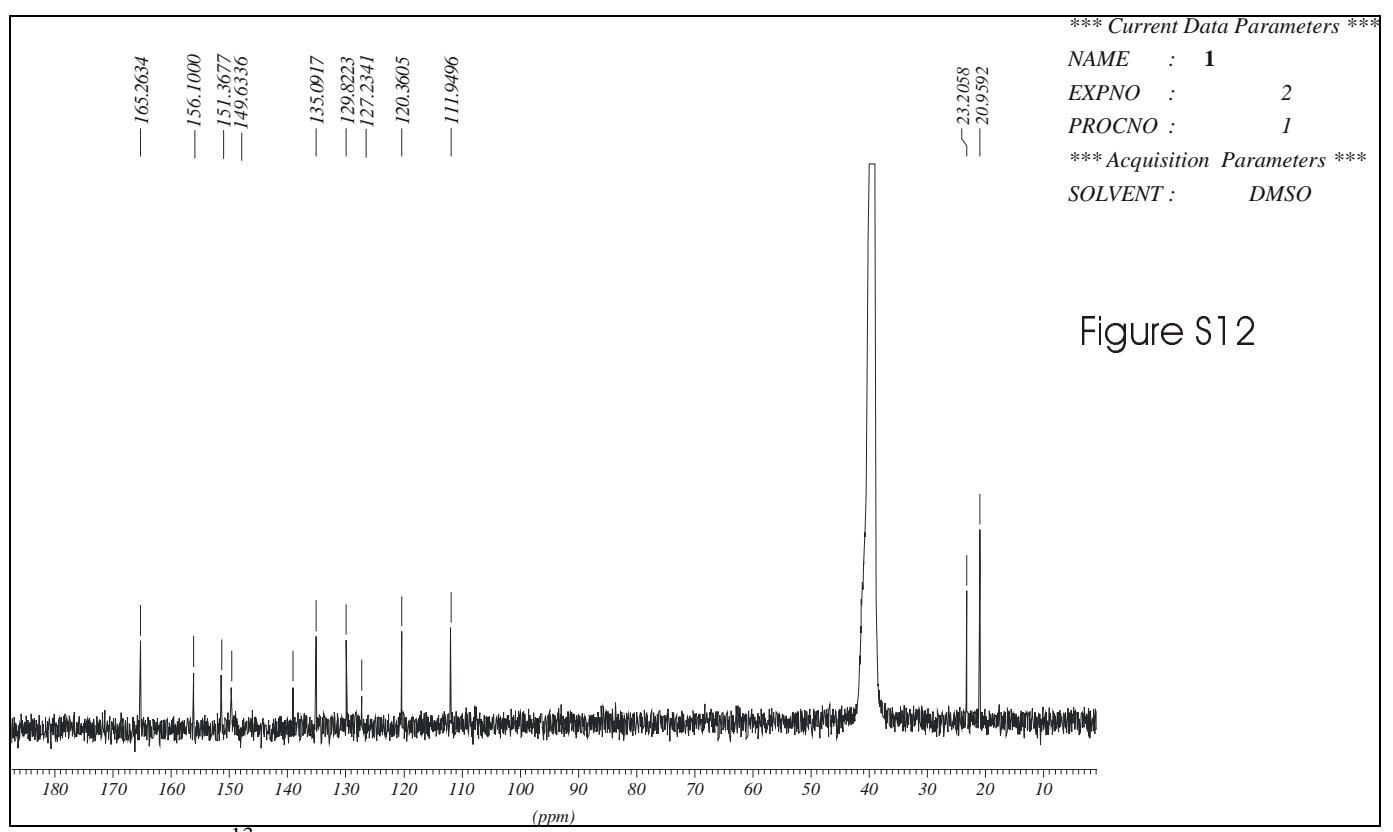

FIGURE S12. ${ }^{13} \mathrm{C}$ NMR Spectrum of 1 (DMSO-d $\left.\mathrm{d}_{6}\right)$.

5. Representative mole ratio plots.

a)

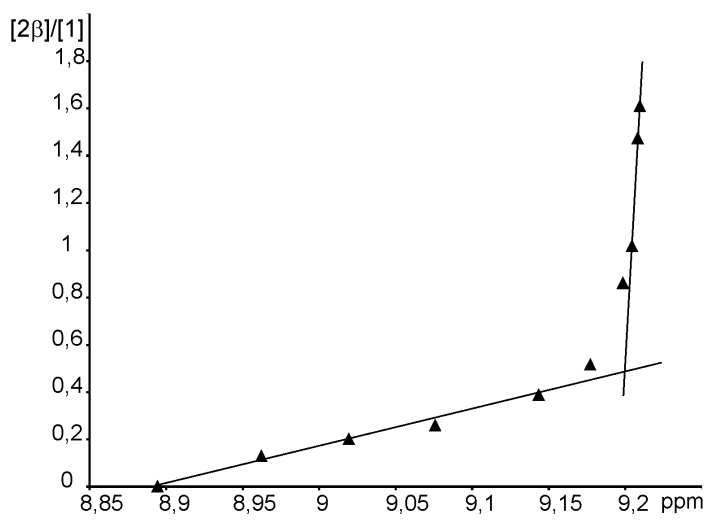

b)

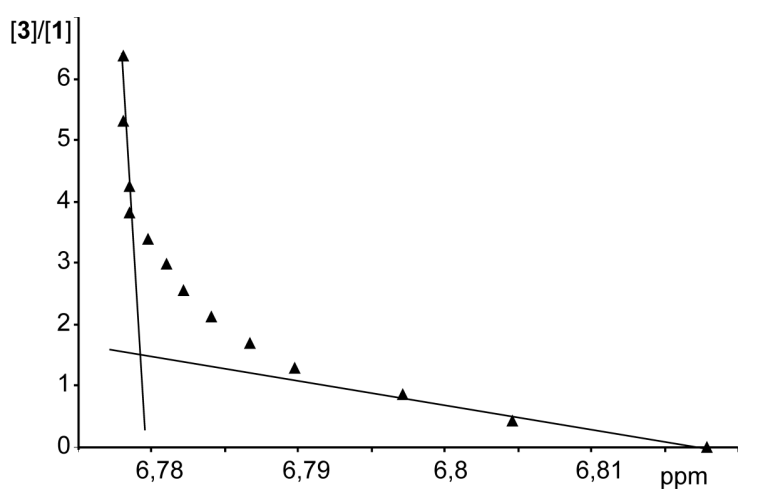

FIGURE S13. Mole ratio plots: (a) Titration of 1 with maltoside $2 \beta$ (analysis of the shifts of the NH protons of $\mathbf{1}$; analysis of the data from the first complexation step). (b) Titration of receptor $\mathbf{1}$ with glucopyranoside $\mathbf{3}$ (analysis of the shifts of the pyridine $\mathrm{CH}$ protons of $\mathbf{1}$ ).

6. Description of a titration experiment with dodecyl $\beta$-D-maltoside (2ß).

Receptor solution: $0.01703 \mathrm{~g}$ of receptor 1 was dissolved in $20 \mathrm{~mL} \mathrm{CDCl}_{3}\left(\mathrm{CDCl}_{3}\right.$ was deacidified with $\mathrm{Al}_{2} \mathrm{O}_{3}$ )

Sugar solution: $0.01405 \mathrm{~g}$ of $2 \beta$ was dissolved in $7 \mathrm{~mL}$ of the receptor solution 


\begin{tabular}{|l|c|c|c|}
\hline & Receptor solution $[\mu \mathrm{L}]$ & $\begin{array}{c}\text { Solution of maltoside } 2 \beta \text { in } \\
\text { the receptor solution }[\mu \mathrm{L}]\end{array}$ & $\begin{array}{c}\text { [maltoside]:[receptor] } \\
\text { ratio }\end{array}$ \\
\hline 1 & 900 & 0 & 0.11 \\
\hline 2 & 870 & 30 & 0.22 \\
\hline 3 & 840 & 60 & 0.34 \\
\hline 4 & 810 & 90 & 0.45 \\
\hline 5 & 780 & 120 & 0.57 \\
\hline 6 & 750 & 150 & 0.68 \\
\hline 7 & 720 & 180 & 0.76 \\
\hline 8 & 700 & 200 & 0.95 \\
\hline 9 & 650 & 250 & 1.07 \\
\hline 10 & 620 & 280 & 1.14 \\
\hline 11 & 600 & 300 & 1.34 \\
\hline 12 & 550 & 350 & 1.53 \\
\hline 13 & 500 & 400 & 1.72 \\
\hline 14 & 450 & 450 & 1.91 \\
\hline 15 & 400 & 500 & 2.10 \\
\hline 16 & 350 & 550 & 2.29 \\
\hline 17 & 300 & 600 & 2.49 \\
\hline 18 & 250 & 650 & 2.68 \\
\hline 19 & 200 & 700 & 2.87 \\
\hline 20 & 150 & 750 & \\
\hline
\end{tabular}

